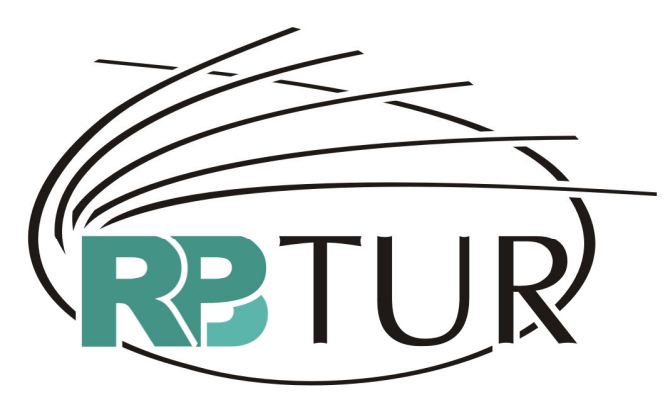

REVISTA BRASILEIRA DE PESQUISA EM TURISMO

\title{
EDITORIAL
}

\section{EDITORS PAGE}

\section{Margarita Barretto ${ }^{1}$ Sênia Bastos ${ }^{2}$}

O conceito de experiência constitui a tônica da primeira edição de 2009 da Revista Brasileira de Pesquisa em Turismo - RBTur. Inaugura-o o artigo "Dialogando com experiências vivenciadas em Marraquech e America Latina para compreensão do turismo comunitário e solidário", de Coriolando e Sampaio, que problematizam o papel potencializador do turismo no resgate de aspectos étnicos bem como na conversão da cultura em espetáculo, que têm sido debatidos no meio acadêmico. $O$ artigo focaliza "as experiências comunitárias de turismo comunitário e solidário (TCS), bem como em entrelaçamentos entre arranjos socioprodutivos e políticos de base comunitária e comércio justo, solidário e sustentável" a partir da pesquisa exploratória realizada em Marraquech/Marrocos.

\footnotetext{
${ }^{1}$ Possui doutorado em Educação pela Universidade Estadual de Campinas (1998), mestrado em Educação pela Universidade Estadual de Campinas (1993) e graduação em Turismo pela Pontifícia Universidade Católica de Campinas (1984). É professora da Fundação Universidade Regional de Blumenau (FURB), pesquisadora do CNPq e Professora Voluntária na Universidade Federal de Santa Catarina. Email: barretto.margarita@gmail.com

${ }^{2}$ Sênia Bastos é bacharel (1990), mestre (1997) e doutora (2001) em História pela Pontifícia Universidade Católica de São Paulo. Atualmente é professora titular do Mestrado em Hospitalidade da Universidade Anhembi Morumbi onde também leciona na graduação do curso de Turismo. Email: seniabastos@gmail.com
} 
BARRETTO, Margarita; BASTOS, Sênia. Editorial. Revista Brasileira de Pesquisa em Turismo v. 3, n. 1, p. 1-3, abril 2009.

ISSN: $1982-6125$

No artigo "Economia da experiência: o consumo de emoções na Região Uva e Vinho" Tonini introduz-nos no campo do enoturismo, cuja atmosfera envolvente inebria o visitante em uma experiência única nas visitações da Região Uva e Vinho, no Rio Grande do Sul: o aroma da uva e o sabor do vinho. Trata da economia da experiência chamando-nos a refletir para a sua essência: "nada mais é que a tradução do consumo de signos, onde o elemento diferenciador, o exótico, o único, se transforma em emoções que traduzem símbolos sociais, distinções $[\ldots] "$.

Sob a perspectiva do morador, o artigo de Carvalho intitulado "Turismo e preservação do patrimônio cultural na visão dos moradores do bairro da Praia Grande em São Luís/MA" problematiza a recriação da cultura para o mercado, no caso, o do turismo. Por meio de uma pesquisa de campo realizada com os moradores do Centro Histórico de São Luís/MA, analisou as representações comunitárias da turistificação do bairro da Praia Grande, reconhecida pela UNESCO como Patrimônio da Humanidade. Resulta de suas conclusões o incipiente contato intercultural entre moradores e visitantes: "A ausência de interacionismo e a descentralização espacial entre moradores e visitantes constituem-se numa das principais problemáticas e que influem diretamente no valor positivo associado a essa atividade". Ressalta-se também a falta de interação dos moradores com o patrimônio, visto que "o vinculam principalmente à fruição turística", distanciamento problemático decorrente da política federal de preservação, cujas ações ainda não são eficazes para a incorporação do patrimônio cultural como lugar de memória e de pertença.

Interação que é perseguida por Loch e Walkowski no Município de Alfredo Wagner/SC, cujo artigo "O processo participativo no planejamento turístico do espaço rural de Alfredo Wagner/SC" relata a experiência de um projeto realizado por meio da metodologia participativa, "visando envolver os agricultores e agentes locais, identificar os possíveis atrativos, incentivar 0 turismo como forma de renda complementar e contribuir para o desenvolvimento sustentável". Alertam para a intermitências de propostas de 
BARRETTO, Margarita; BASTOS, Sênia. Editorial. Revista Brasileira de Pesquisa em Turismo v. 3, n. 1, p. 1-3, abril 2009.

ISSN: 1982-6125

trabalhos isolados, que não apresentam continuidade, desmotivando os atores sociais.

No artigo teórico "Estruturação de matriz de impactos do turismo: o caso do agroturismo no município de Santa Rosa de Lima/SC" Pires, Anjos, Oliveira e Silva apresentam uma matriz de impactos do turismo, que foi aplicada ao município de Santa Rosa de Lima/SC.

Encerra a edição a resenha do livro de Camargo (2007) "Uma préhistória do turismo no Brasil. Recreações aristocráticas e lazeres burgueses (1808-1850)" de Marcelo. 